\title{
Consumption and Sustainable Development: Ethical Aspects
}

\author{
Konsumpcja i zrównoważony rozwój: aspekty etyczne
}

\author{
Maria Miczyńska-Kowalska \\ Faculty of Agrobioengineering, Institute of Agricultural Sociology \\ University of Life Sciences in Lublin, Poland \\ E-mail: Maria.Miczynska@up.lublin.pl
}

\begin{abstract}
Economic growth, excessive consumption and the consequent growing exploitation of natural resources pose the risk of a global ecological disaster. Therefore, it is vital to create a new consumer awareness concerned about the natural environment. This paper describes the issue of sustainable consumption in the context of sustainable development. It has been assumed that the increasing popularity of ecological awareness, plays the key role in the implementation of the objectives of sustainable consumption and sustainable development. The aim of this paper is to explain mechanisms responsible for the increasing role of consumption in the modern world and to draw attention to the need to raise the ecological awareness of consumers. The paper uses the analytic-synthetic method.
\end{abstract}

Key words: consumption, sustainable consumption, sustainable development, consumerism, ecological awareness, labour, Catholic social teaching

\section{Streszczenie}

Wzrost gospodarczy, nadmierna konsumpcja, a w konsekwencji rosnąca eksploatacja zasobów naturalnych, stwarzają ryzyko globalnej katastrofy ekologicznej. Dlatego ważne jest, aby kreować nową świadomość konsumentów dotyczącą środowiska naturalnego. W artykule opisano zagadnienie zrównoważonej konsumpcji w kontekście zrównoważonego rozwoju. Założono, że rosnąca popularność świadomości ekologicznej odgrywa kluczową rolę w realizacji celów zrównoważonej konsumpcji i zrównoważonego rozwoju. Celem tego artykułu jest wyjaśnienie mechanizmów odpowiedzialnych za rosnącą rolę konsumpcji we współczesnym świecie oraz zwrócenie uwagi na potrzebę podnoszenia świadomości ekologicznej konsumentów. W pracy wykorzystano metodę analityczno-syntetyczną.

Słowa kluczowe: konsumpcja, zrównoważona konsumpcja, zrównoważony rozwój, konsumeryzm, świadomość ekologiczna, praca, katolicka nauka społeczna

\section{Introduction}

Consumers are increasingly concerned about environmental protection. More and more often, they become aware of the relation between their own actions and other areas of social and economic life. They make informed choices about ecological products and reduce excessive consumption because they are aware that their individual consumption may impact their environment. This affects the standard of living and quality of life of the whole society. Quality of life is related to standard of living and fulfilling one's material and spiritual needs. It is a sociological and psychological category. Quality of life is, in a way, a subjective self-evaluation regarding life satisfaction or dissatisfaction of an individual. Standard of living, however, encompasses quality of life, as well as life standards and social welfare. Social welfare is associated with: ownership (includes the aspect of consuming goods and services), feelings (includes interpersonal relations), shift in consumer's profile and their awareness (being open-minded about the new, change of lifestyle etc.). Thus, the higher the quality of life, the greater the consumption, its change and the priority of the modern consumption (Małysa-Kaleta, 2002). The shift from anthropocentric to biocentric awareness is currently ongoing, although sometimes opposed and not always uniform. 
The awareness regarding the necessity to change from unsustainable to sustainable consumption is present mainly in the Western culture. Therefore, it is vital to create a new consumer awareness concerned about the natural environment. It is important that today's consumer does not perceive lavish consumption as an indicator of status and prestige; and that an individual does not treat consumption, especially material goods, as their basic source of satisfaction, for the orientation on the Frommian notion of possessing is the foundation for unsustainable consumption. Consumer behaviour is motivated by certain values. People's value systems must thus be arranged in accordance with the sustainable consumption model. Well-shaped patterns for sustainable consumption lead to achieving a better quality of life through less expensive, healthier products in a cleaner environment. Creating a biocentric awareness requires education which would enable a change in mentality, bringing about a dematerialisation of needs. The most apt people for this task are scholars, public figures, distinguished people, idols of today's youth and the most wealthy. The author of this paper argues that consumer behaviours are determined by the consumer's values. The study noted that with the appearing of the risks connected with the protection of the environment, as a result of dynamic economic development, the idea of sustainable development has become valuable. This is related with the negative effects of development, which largely is based on consumption. Excessive consumption may, however, lead to the devastation of Earth's resources. That is why today, sustainable consumption has big importance in sustainable socio-economic development.

\section{The sustainable development of society}

The emergence of the idea of sustainable development was imposed by the environmental crisis in the second half of the $20^{\text {th }}$ century. There are various definitions of sustainable development in the literature. There is the natural approach, emphasising the adaptation of economic and social activities to the existing capabilities of ecosystems; the economic approach - indicating the need to balance the economic activities with the current ecosystem productivity; and the civilisational approach - which aims at achieving a balance in the context of the latest scientific achievements (Jalinik, 2009).

The author decided that the more appropriate term for the purposes of this article is sustainable development rather than environmentally-friendly development. The term environmentally-friendly development restricts the understanding of future threats to environmental factors. However, they are not the only threats caused by socio-economic development, so choosing this term would restrict the subject matter (Sadowski, 2000).
Contemporary societies can be likened to organisms which are subject to not only positive, but also negative factors of change, which include ideologies, ill-conceived economic decisions, etc. FFP (Fund For Peace) prepares the annual Fragile States Index, assessing which states present the greatest risk to the international community. The parameters listed include demographic pressures; refugees \& IDPs, group grievance; human flight; uneven economic development; economic decline; state legitimacy; public services; human rights \& rule of law; security apparatus, factionalized elites. (Ostaficzuk, 2015). It is a list which also shows the level of potential threats to the human community. One significant threat turns out to be rapid economic development, which is closely tied to increase in consumption. Therefore, nowadays, it is talking about sustainable consumption and production. Defining Sustainable Consumption and Production United Nations World Summit on Sustainable Development:

- To promote social and economic development,

- Within the carrying capacity of ecosystems,

- $\quad$ By addressing and, where appropriate, de-linking economic growth and environmental degradation,

- Through improving efficiency and sustainability in the use of resources and production processes,

- And reducing resource degradation, pollution and waste (Johannesburg Plan of Implementation, UN World Summit on Sustainable Development, 2002).

In this context, the concept of sustainable development involves striking a balance between economic growth, social progress and environmental protection.

Sustainable development is development that meets the needs of the present without

compromising the ability of future generations to meet their own needs. It contains within it two key concepts:

- $\quad$ the concept of 'needs', in particular the essential needs of the world's poor, to which

overriding priority should be given; and

- the idea of limitations imposed by the state of technology and social organization on the environment's ability to meet present and future needs (WCED, 1987).

The objective of sustainable development is to increase well-being in the individual and social dimensions. The goals of economic and social development must be defined in terms of sustainability in all countries - developed or developing, market-oriented or centrally planned (WCED, 1987). It depends not only on the consumption of goods and services but also on ecological conditions. The objective of development is, therefore, not only to achieve certain living standards, but also to improve the quality of life (Janoś-Kresło, Mróz, 2006). 
Sustainable development only exists when the following development dimensions are taken into account: (Pearce, Turner, 1990) environmental - economic growth respecting environmental protection; social - the well-being of mankind is evenly distributed; economic - there is no reduction in economic growth; psychological - the quality of life increases; spatial - involves sustainable regional development taking into account the protection of the environment and cultural heritage; demographic - demographic processes (too high or too low birth rate) do not cause significant disturbances in the functioning of the economy and society.

Popularising environmental awareness, which remains closely tied to the principles of CST, plays an important role in the evolution of achieving the objectives of sustainable development.

The concept of sustainable consumption remains closely tied to the concept of sustainable development. Similarly, the ideas contained in the social documents of the Church are currently in agreement with the principles of the concept of sustainable development.

\section{Ecological awareness and consumption, consum- erism and consumer movement}

Environmental protection is one of the most significant issues for today's world. Some believe that putting a stop to environmental degradation and repairing damage that has already been caused is a condition necessary for the civilisation to survive on a global scale. It is also consumption that is considered to be the most dangerous factor for environmental degradation (Wiśniewski, 1995). At present, consumption is closely related to lifestyle and the ways of satisfying one's needs. Both overconsumption in highly developed countries and the lack of environmental protection in less industrialised ones are the causes of environmental degradation observed in the world. A counter-measure would be to increase customers' ecological awareness and understand that a lifestyle based on limiting overconsumption and, consequently, the amount of produced waste is highly desirable for the environment.

The term ecological awareness has received different definitions in the literature. In this article, ecological awareness is understood as the feeling of responsibility of a person for their actions in the environment. Ecological awareness is the customers' pattern of behaviour focused on choosing products and satisfying needs in a such a way as to avoid causing harm to environment, including one's and other people's health as an element of the environment (Wiśniewski, 1995). The terms consumption and consumer movement come from Latin. consumerism comes from Latin consumptio - consumption and consumer movement from consumer - consume.
Consumption may be understood in a broader or narrower sense. The narrower sense defines consumption as consuming material goods which are an effect of labour. In the broader sense, consumption means satisfying any existential needs, including those of socio-energetic, informational, rational and emotional nature, aimed at biological survival, but also those determined by a sense of security and pleasure. (Leszczak, 2012). Balance should be maintained between work and consumption.

Consumerism, on the other hand, appears when the balance is upset and the gravity shifts towards consumption. As a result, consumerism is a tendency disturbing the balance between work and consumption tipping the scales towards the latter. Consumption is a natural process of management, stemming from the necessity to satisfy one's needs. Consumerism is its corrupted form. It is an attitude of putting material goods before other assets. Consumerism is often understood as excessive consumption, unjustifiable by the person's real needs.

In sociology, consumerism is described as a form of social life. Z. Bauman claims that it is a type of a social arrangement rooted in secondary processing of human needs, desires and longings into a driving force of the society, which coordinates the system's reproduction, social integration, stratification and shaping of individuals but also plays an important part in the processes employed in the creation of individual and group identity as well as in the choice of life strategies (Bauman, 2009).

Another meaning of consumerism used frequently in the literature is an equivalent of consumer movement. It denotes activities aimed at protecting consumers and representing their best interest before manufacturers, which are undertaken in order to maintain balance between manufacturers, the state and the final consumers. The most common forms of consumer movement include: antitrust laws, product safety standards, quality testing, combating unfair competition etc. (Gazda, 2012).

Sociologists indicate that the modern world observes consumption becoming a new religion based on the following assumptions (Badiner, 2002):

1. Economic growth and developed global trade will be beneficial for us all.

2. The growth will not be inhibited by any measurable natural boundaries.

In fact, one of the basic sources of risks for the modern world is the constant, rapid economic growth. The growth is based on surging industrial production and results in increasing consumption of material goods.

Mankind is thus faced today with the issue of creating sustainable societies. Sustainable society is one whose lifestyle, entrepreneurship, economy, physical structures and technologies do not interfere with nature's capability to sustain life (Capra, 2004). Our 
first task is to comprehend and implement ecosystem principles. Still, one of the most important barriers for ecological development is material consumption arising from holding particular values. The new economy is also a threat, as it is focused on processing information and generating knowledge and its main purpose is to further develop production and enhance flow of goods, dismissing the principles of ethical and ecological social development.

Anthropologist David Gilmore believes that the glorification of material consumption is deeply rooted ideologically. It reaches further than economy or politics. Its source can be traced to patriarchal cultures, where manhood was associated with material possessions. Gilmore points out that, according to his research, traditionally, a true man is the one who produces more than consumes (Gilmore, 1990). In a modern society prestige is achieved through accumulating possessions. The ecological movement linked with feminist awareness opposes the ambition of gaining wealth. Individuals involved in this movement propose a transmission from a goods economy to a service-flow economy. This type of economy features a steady flow of materials, which reduces resource exploitation. Waste is used as resource, conducing to higher productivity. The advantage of the service-flow economy (zero-emission, sustainable) lies in the improved effectiveness regarding the use of resources, reduced pollution and more opportunities of employment in particular branches of the economy.

\section{Consumption and work - ethical aspects}

Overconsumption as well as wastefulness are typical for dominant societies. Conspicuous consumption is seen as a symbol of power. Yet, nowadays the biggest challenge mankind is presented with are the effects of increased production and overconsumption - an economic crisis. We are therefore dealing mainly with a moral problem - how to stop the desire for consumption which drives people today. How to create a sustainable economy, a zero-emission society. It is important to point out the role of socialisation and upbringing in a consumer society, as the values we share determine our life orientation as well as our choices, including consumer choices.

In a consumer society, consumption is of key importance. It is linked with one's social status. In sociology, status-goods oriented consumption is known as prestige consumption (Burghard, 1974). Consumption becomes an element of a consumerist lifestyle. Similarities in consumption capacity is displayed by the style of life (Sztompka, 2002). Lifestyle is a culturally conditioned method of satisfying one's needs. It is regulated by the value system adopted by an individual or a group. Social entities which realise specific lifestyles, represent particular segments of the social structure and, consequently, features of a particular status and economic position.
The category of lifestyles, and consumption at the same time, is closely related to the emergence of the middle class, also known as white-collar, in the industrial society (Savage, 2012). Other stratification conditions in the society connected with the styles of life, including non-economic ones, were pointed out by M. Weber (Weber, 1991). The very term consumer society appeared in social sciences in the second half of the 20th century. It denoted a new form of capitalism. The issue of a capitalist society was first described by J.K. Galbrieth, G. Katon, H.D. Ortlieb.

Consumption affects customs and traditions, social and cultural values but also morality. All this is due to the influence of the consumer culture and the ideology of consumerism in a broad sense. This is why the lifestyle of individuals living in a consumer society should be changed. The answer to environmental protection issues is sustainable, ecological consumption. This lifestyle involves generating consumers' interest in non-material goods, dematerialisation (consumers treat material goods as a service medium, not as a source of satisfaction and prestige). By and large, it is about the rationalisation of use of goods and producing relatively little waste. The harmful effects of environmental degradation lead to the emergence of a concept of durable consumption. In practice, the above mentioned concept is the starting point for sustainable consumption policy. It is based on the following principles: durability, sustainability, solely preservation (Bylok, 2013).

In public discussion on social, economic and ecological effects of excessive consumption the attention is drawn to the fact that economic growth should bring improvements in the quality of life, not consumption as such or the accumulation of material goods. Quality of life covers not only the consumption level but also other aspect of human life, including the state of natural environment.

Many professionals and scholars nowadays apply ethical perspective to the problem of increased consumerism. They underscore the fact that overconsumption displayed by the wealthy in developed capitalist countries is possible only at the expense of less developed countries. Scholars claim that since the planet's resources are limited, it is impossible for everyone to achieve the same consumption and standard of living. Consumerism is bashed by them also owing to the fact that it conduces to the wastefulness of products and, through that, wastefulness of human work, devastation of non-renewable natural resources, thus contributing to spiritual degradation of mankind.

As the ecological awareness grows, consumers begin to notice the need to adopt ecological lifestyle and ecological consumption. It is a tendency including, e.g. avoiding (Peattie, 2001): products posing risk to consumer's health and their environment; causing environmental degradation in the process of manu- 
facturing, use or discarding of the product; involving great amounts of resources; created from resources dangerous for people and their environment; contributing to unnecessary wastefulness (e.g. unnecessary additional packaging); breaching animal rights in the process of manufacturing.

To explain changes linked with the growing importance of consumption in the modern society, one must consider the transformation in the work-consumption relationship.

In the industrial society the axionormative order was created on the foundation of religion and work, not the level of consumption. From the sociological viewpoint, work was a point of reference for building one's sense of identity, self-fulfilment, prestige and social status (Bylok, Swadźba, Walczak-Duraj, 2016). The sociological reflection on work was accompanied by ethical thought, on the one hand focused on moral attributes of work as perceived by an individual, on the other hand on its relative, ethically marked social context (Bylok, Swadźba, WalczakDuraj, 2016). In his work, The Protestant Ethic and the Spirit of Capitalism, M. Weber argues that values and the underlying concepts of religion are also reflected in the socio-economic order.

The issue of work is also brought up in social documents of the Catholic Church, in papal encyclicals: Leo XIII's of 1891 - Rerum Novarum, Pius XI from 1931 - Quadragesimo Anno, John Paul II of 1981 Laborem Exercens and of 1991 - Centesimus Annus. Moreover, John Paul II describes the issue of environmental protection in the socio-economic growth resulting from human work. This subject is also present in Francis' encyclical Laudato si'. As the status of labour in the consumer society changes and the emphasis is placed on consumption rather than work, all areas of social life as well as the axionormative and economic order witness a change. What differentiates the standard of life in the postindustrial society and, at the same time, determines to which status group one belongs, is the ownership and consumption of luxury goods. This phenomenon accompanies the unlimited access to goods and a constantly increasing income. (Bylok, Swadźba, Walczak-Duraj, 2016).

In the post-industrial, consumer society consumerism is taking over functions formerly represented by the Church. In an individualistic society individuals seek religious bonds and find them in the consumer culture. Shopping centres are such consumer shrines (Ritzer, 2004). In a shrine, people feel happy at least briefly, they feel they belong to a temporary group of consumers. The appeal of consumerism lies in its construction. It does not require any sacrifices and provides an illusion of happiness. This ideology is not institutionalised, but it is very expansive. Both the wealthy and the less well-off join the new religion.

Sociologists draw attention to the fact that the consumer world is secularised. The spiritual life is mar- ginalised. Still, the new form of religion does not provide answers to difficult existential questions, it does not always bring consolation (Badiner, 2002). Conversely, it often leads to despair and social degradation. It condemns its believers to emptiness and despair. (Dziura, Wolanin-Jarosz, 2014).

\section{Social development concepts in Catholic Social Teaching}

Issues relating to the concept of labour, and thereby consumption and dysfunctions in social development, are present in Catholic Social Teaching. In the context of CST, it is pointed out that having possessions is an aspect of human nature. Man is the subject of labour and has the right to subdue the earth and its resources to his needs. Man also has the right to development. The right of ownership is tied with the rational nature of man and freedom. Strzeszewski emphasises that a considerable body of historical evidence for the existence of property in the earliest epochs of mankind is provided as early as in the Books of the Old Testament (Strzeszewski, 1981). However, man must not forget that the right of use takes precedence over the right of possession of property.

Leo XIII criticised socialism for dispensing with private property, as he sought to bridge the gap between labour and capital, while giving precedence to labour over capital. He wrote that work not only does not humiliate man, but is a source of dignity, as it provides a means to sustain life (Leo XII, 1891). Pius XI expressed similar views. He stressed that human labour is not a commodity and that its value should be recognised. The true value of labour and its rights cannot be determined without taking into account its social and individual nature(Pius XI, 1931). In Laborem Exercens, John Paul II developed the subjective dimension of labour and its priority over capital (John Paul II, 1981). According to the Pope, the realisation of the right to work depends not only on the economic development of a given country, or the sum of goods held, but primarily on the fair distribution of material goods and access to cultural assets. Labour is the most common way which allows man to acquire means of living and maintenance and hold possessions. With few exceptions, nature does not provide final goods (Poszwa,1938). This means that man must adapt the earth's riches for consumption through work, as he receives nothing in a ready state. Unequal economic development in various areas of production, as well as in different regions within a given country, and in different areas of the world is a dangerous phenomenon, as it increases the fortunes of a group of people in certain regions, or even whole nations, while deepening the poverty of many other people, especially those who work in less developed fields of production, such as agriculture, among those who live in a country's agricultural, rather than indus- 
trialised, areas and among the populations of countries with underdeveloped industry and economies. In this context, John XXI points out that the disproportions in the economic development of individual regions within the same country, as well as between countries, cause excessive migration, which is a highly unfavourable phenomenon. To provide for the common good of all mankind, as noted by Paul VI, greater justice must be introduced in the distribution of goods, be it national or international (Paul VI, 1967). The Pope supported the development of all kinds of international campaigns and international institutions working to protect human dignity. In Populorum Progressio, Paul VI wrote that the fundamental right of human society is the right to development. He introduced this right as a synthesis of an individual's personal rights. The Pope perceived development not only as a right, but also as a responsibility (Paul VI, 1967). The substance of personal development is realised in seeking to have more in order to be more. According to the Pope, however, economic growth is not the only objective of development (Paul VI, 1967). It is, however, the essential component of integral development of man and mankind at large. This is consistent with the keystone of Catholic Social Teaching which sees the pursuit of the common good as the goal of development. And development goes hand in hand with progress. But progress without ethical values becomes its negation and leads to dehumanisation in social and economic life. Paul VI spoke of two ethical values, which in his view should be the foundations of development of societies: acquiring goods in the service of all men and building solidarity on a universal scale (Paul VI, 1967). The international community is the highest form of society, and the ultimate stage of social development. It is also a manifestation of human integration, although it should be understood as a unity of multiplicity. Economic development, which is aimed at fulfilling the needs of the whole society/mankind, is part of general social development. Social development, in turn, is expressed in progressively higher forms of societal culture. In the Pope's view, cultural development must not be omitted in social development. John XXIII had spoken about this matter previously, emphasising that Christians should cooperate with people from different cultures.

John Paul II expressed similar views. The focus of his reflection on culture and civilisation was the human person. The actions of man remain at the centre of his attention. Despite the fact that Karol Wojtyła gave special emphasis to ethical and philosophical issues, he did not avoid issues of socio-economic development, international situation, labour, consumption and environmental protection. The concept of the economic system also had an important place in his reflection. According to the Pope, dialogue is the foundation of a peaceful order in human relationships, as well as in international relations
(John Paul II, 1991). He supported the idea of ecumenism, interfaith dialogue, as well as full participation of laypeople in the life of the Church community. John Paul II did not equate religiousness with Christianity, as he understood it as a common and universal feature of mankind (Modrzejewski, 2009). With regard to the philosophy of economics, the Pope's teachings are an attempt to bridge economic liberalism and Marxist socialism. CST, and largely John Paul II's socio-economic concepts, represents the Third Way created as a compromise between capitalism and socialism. The Pope's reflection is sometimes seen as a kind of universalism, which involves transcending the axiological and institutional barriers set by the concepts of industrial society and creating a new vision of socio-economic, cultural and political order, in which elements of socialism are combined with elements of economic liberalism under classical, universalistic values (Modrzejewski, 2009). John Paul II supported the basic principles of free market economy, but not unconditionally. He assumed the reconstruction of free market systems in the spirit of religious values, which means subordinating the economy to the human being. In the context of general social justice, he argued that a fair socio-economic system should take into account the demand for the collective ownership of the means of production - employee stock ownership, which had been previously described by Leo XIII. John Paul II did not perceive economic freedom or private property as absolute values. In CST, use has priority over ownership. The Pope did not condemn economic activity aimed at achieving profits, He attached great significance to human labour and its value, seeing work as an expression of self-creation and improvement of the human person. He noted that the globalisation and liberalisation of trade contribute to deepening social divisions and the marginalisation of certain social groups. Consequently, he opposed the unequal development of various countries of the world, which lead to the domination of the strong over the weak. Economic development according to JPII is not an end in itself. It should rather be subordinated to the development of the human person (John Paul II, 1991). He claimed that economic development should provide acceptable living conditions to the individual. However, it should be subordinated to cultural development. The Pope acknowledged that man cannot achieve happiness through the accumulation of goods, as people need an integrated vision of development and satisfying their spiritual needs (John Paul II, 1991). Among the human needs which must be addressed, JPII also saw an unpolluted national environment. In the Pope's view, problems connected with the environmental crisis require international-level solutions (John Paul II, 1990). In papal philosophy, sustainable development involves striking a balance between economic progress and the need to protect the natural and cultural environ- 
ments. He placed the latter at the centre of attention, as he believed that it is these environments that are most often disregarded in the modern world. In his view, more attention should be given to issues related to the natural environment. JP II strongly opposed the rampant ideology of consumption, which reduces the vision of development to increased consumption. John Paul II noted that people who spurn God and fellow human beings affirm their own selfinterests (John Paul II, 1991). That is why they are filled with an insatiable greed for profit and consumption.

In the Pope's view, consumerism leads to the degradation of the natural environment, causes negative social consequences, and a disregard for the human being as a person. According to John Paul II, true growth involves the moral development of man.

The current Pope, Francis, in his encyclical Laudato $s i$ ', notes the community dimension of progress, in line with the leading concept of Catholic Social Teaching (Francis, 2015). However, he primarily refers to the subject of the degradation of the natural environment, which has been the negative impact inherent in economic development (and which is a growing problem these days). According to the Pope, the negation of the problem of environmental protection is caused by indifference, resignation or blind faith in technical solutions. With regard to the environmental problem, he brings attention to seeking alternative ways of understanding economics and progress. He emphasises the significance of protecting natural values and the responsibility of people for their actions which lead to the degradation of the natural environment (Francis, 2015). The Pope asserts that the rapid changes of the modern world do not always lead to a sustainable and integral development of societies. Therefore, he urges people to change their lifestyles and methods of production and consumption (Francis, 2015).

In general, the authors of Catholic Social Teaching take the position that there is a need to introduce restrictions on development. In their view, economic development must not be opposed to human being. They see overconsumption as contributing to moral decline. The Popes claim that economic development should be creative, which means that it must not destroy natural resources in the process, but rather enhance them; furthermore, it must not destroy man, but improve him; it must not introduce socioeconomic disparities, but aim at their reduction on an international scale.

Sustainable consumption is currently a much-discussed topic in public and academic debate. It involves the use of goods and services that respond to basic needs and bring a better quality of life, while minimizing the use of natural resources, toxic materials and emissions of waste and pollutants over the life cycle, so as not to jeopardize the needs of future generations (Berbeka, 2002). The definition of sustainable consumption should involve the following two dimensions: (Kiełczewski, 2008) normative (which defines the desired form of consumption processes) and descriptive (describing the economic conditions to be met for the real consumption processes to achieve the goals of sustainability).

Sustainable consumption is linked with the ethics of consumption. The ethics of consumption concerns the moral reflection on the economic aspects of using people, animals and the natural environment to respond to needs (Senyszyn, 2002).

\section{Conclusion}

In modern capitalist societies, consumption has become the foundation of a well-functioning economy. Sociologists report the increasing role of materialistic value systems and a consumerist lifestyle, as well as the invasion of hedonism. A wide-ranging expansion of consumerist culture is connected with the phenomenon of consumer imperialism (Mróz, 2009). In contemporary times, in a society defined as a consumer society, consumption plays a greater role than only economic. First of all, individuals define themselves through consumption, so it becomes an instrument of self-definition; secondly, it is through consumption that individuals communicate their inclinations, tastes and preferences and express their outlook and philosophy of life.

With the emergence of greater consumer environmental awareness and the appearance of the concept of sustainable consumption, there is a growing need to focus on the protection of the Earth's natural resources and sustainable development. The values contained in the papal social teaching may prove helpful in the implementation of the environmental and ethical priorities of development.

\section{References}

1. BADINER A. H., 2002, Mindfulness in the Marketplace: Compassionate Responses to Consumerism, Parallax Press, Berkeley.

2. BAUMAN Z., 2009, Konsumowanie życia, Wydawnictwo UJ, Cracow.

3. BERBEKA J.,2002, Ocena konsumpcji w Polsce w świetle założeń zrównoważonej konsumpcji, in: Konsumpcja $i$ rynek $w$ warunkach zmian systemowych, ed. Kędzior Z., Kieżel E., Polskie Wydawnictwo Ekonomiczne, Warsaw.

4. BURGHARD A., 1974, Allgemeine Wirtschaftssoziologie, Verlag Dokumentation, Pullach bei Munchen.

5. BYLOK F., 2013, Konsumpcja, konsument i spoteczeństwo konsumpcyjne we wspótczesnym świecie, Śląsk Sp. z o.o. Wydawnictwo Naukowe, Katowice.

6. BYLOK F., SWADŹBA U., WALCZAK-DURAJ D., 2016, Praca i konsumpcja w perspektywie tworzenia tadu aksjonormatywnego, Sląsk Sp. z o. o. Wydawnictwo Naukowe, Katowice.

7. CAPRA F., Patriarchalne korzenie nadmiernej konsumpcji, 2004, in: Uważność na targowisku. Globalny rynek i masowa konsumpcja a świadome życie, ed. Badiner A.H., Wydawnictwo Jacek Santorski \& Co, Warsaw. 
8. DZIURA M., WOLANIN-JAROSZ E., 2014, Homo consumens. Kultura konsumpcji, Wydawnictwo KUL, Lublin.

9. FRANCIS THE POPE, 2015, Laudato Si; , Vatican.

10. GAZDA Z., 2012, Konsumpcja a konsumpcjonizm. Odwołanie do historii myśli ekonomicznej, in: The peculiarity of man. Życie w konsumpcji - konsumpcja $w$ życiu-konsumpcja życia, ed. Stefański R, Współczesny człowiek w społeczeństwie konsumpcyjnym, 5.

11. GILMORE D., 1990, Manhood in the Making, Yale University Press, New Haven.

12. JANOŚ-KRESŁO M., MRÓZ B., 2006, Konsument $i$ konsumpcja we współczesnej gospodarce, Szkoła Główna Handlowa. Oficyna Wydawnicza, Warsaw.

13. JOHN PAUL II, 1981, Laborem Exercens, Vatican.

14. JOHN PAUL II, 1991, Centesimus Annus, Vatican.

15. JOHN PAUL II, 1990, Pokój z Bogiem Stwórcą - pokój z całym stworzeniem, in: Życie katolickie.

16. JALINIK M., 2009, Uwarunkowania i czynniki rozwoju ustug turystycznych na obszarach wiejskich, Wyd. Politechniki Białostockiej, Białystok.

17. JASTRZEBSKA-SMOLAGA H., 2000, $W$ kierunku trwałej konsumpcji. Dylematy, zagrożenia, szanse, Wydawnictwo Naukowe PWN, Warsaw.

18. KIEŁCZEWSKI D., 2008, Konsumpcja a perspektywy zrównoważonego rozwoju, Wydawnictwo Uniwersytetu w Białymstoku, Białystok.

19. LEON XII, 1891, Rerum Novarum, Vatican.

20. LESZCZAK O., 2012, Paradoksy konsumpcjonizmu. Typologia i lingwosemiotyka, in: The peculiarity of man. Życie w konsumpcji - konsumpcja w życiu-konsumpcja życia, ed. Stefański R, Współczesny człowiek w społeczeństwie konsumpcyjnym, 5 .

21. MAŁYSA-KALETA A., 2002, Konsumpcja w kształtowaniu jakości życia Polaków, in: Konsumpcja $i$ rynek $w$ warunkach zmian systemowych, eds. Kędzior Z., Kieżel E., Polskie Wydawnictwo Ekonomiczne, Warsaw.

22. MODRZEJEWSKI A., 2009, Uniwersalistyczna wizja tadu światowego $w$ personalistycznej optyce Karola Wojtyly - Jana Pawta II, Wydawnictwo Uniwersytetu Gdańskiego, Gdańsk.

23. MRÓZ B., 2009, Consumo ergo sum? Rola konsumpcjonizmu we współczesnych społeczeństwach, in: $\mathrm{Ob}-$ licza konsumpcjonizmu, ed. Mróz B., Oficyna Wydawnicza Szkoła Główna Handlowa w Warszawie, Warsaw.
24. OSTAFICZUK S., 2015, Zrównoważony rozwój. Problemy bezpieczeństwa, trwania i rozwoju ludzkości; czas postęu i niszczenia, rozwoju myśli i technologii, komfortu egzystencji, marnotrawstwa i dewastacji, Cz. 1, Wydawnictwo IGSMiE PAN, Cracow.

25. PAUL VI, 1987, Sollicitudo Rei Socialis, Vatican.

26. PAUL VI, 1967, Populorum Progressio, Vatican.

27. PAUL VI, 1999, Octogesima adveniens, List apostolski z okazji 80 rocznicy ogłoszenia encykliki 'Rerum Novarum', TUM, Wrocław.

28. PEATTIE K., 2001, Towards Sustainability, The Third Age of Green Marketing, in: The Marketing Review, 2.

29. PEARCE D., TURNER R., 1990, Economics of Natural Resources and the Environment, Harvester Wheatsheaf, New York.

30. PIUS XI, 1931, Quadragesimo Anno, Vatican.

31. POSZWA A., 1938, Ku nowemu ustrojowi, Płock.

32. RITZER G., 2004, Magiczny świat konsumpcji, Warszawskie Wydawnictwo Literackie Muza, Warsaw.

33. JOHANNESBURG Plan of Implementation, UN World Summit on Sustainable Development, 2002, Johannesburg.

34. SADOWSKI Z., 1998, Ekorozwój a wzrost gospodarczy, in: Sterowanie ekorozwojem, t. 1, Teoretyczne aspekty ekorozwoju ed. Poskrobko B., Wyd. Politechniki Białostockiej, Białystok.

35. SAVAGE M., 2012, Status, Lifestyle, and Taste, in: The Oxford History of Consumption, ed. Trentmann F., Oxford University Press, Oxford, New York.

36. SENYSZYN J., 2002, Etyka konsumpcji, in: Konsumpcja $i$ rynek $w$ warunkach zmian systemowych, eds. Kędzior Z., Kieżel E., Polskie Wydawnictwo Ekonomiczne, Warsaw.

37. STRZESZEWSKI C., 1981, Własność. Zagadnienie spoteczno-moralne, Ośrodek Dokumentacji Studiów Społecznych, Warsaw.

38. SZTOMPKA P., 2002, Socjologia, Wyd. Znak, Cracow.

39. WCED (World Commission on Environment and Development), 1987, Our Common Future, Oxford University Press, New York

40. WEBER M., 1991, Class, Status, Party, in: From Max Weber. Essays in Sociology, eds. Gerth H., Milles W., Routledge, London.

41. WIŚNIEWSKI A, 1995, Świadomość ekologiczna konsumentów polskich, Fundacja Friedricha Eberta w Polsce, Warsaw. 